\title{
Tomato growth, yield, and quality response to mixed chemical-organic fertilizers and grafting treatments in a high tunnel environment
}

\author{
Fairuz Buajaila, Jeremy S. Cowan, Debra Inglis, Lynne Carpenter-Boggs, and Carol Miles
}

\begin{abstract}
Tomato (Solanum lycopersicum L.) is a major vegetable crop world-wide and grown in high tunnels in many regions. This study investigates the use of two fertilizer sources, chemical and integrated (composted poultry manure plus urea) fertilizers, and grafting on growth, nitrate-N content, yield, and fruit quality of tomato grown in high tunnels in northwestern Washington. Grafting treatments consisted of 'Panzer' tomato grafted on one of three tomato rootstocks 'Estamino', Maxifort', 'DRO138TX', or non-grafted (control). Application of chemical fertilizer increased number of leaves per plant, plant height, and cumulative fresh biomass of pruned suckers relative to tomato plants grown with the integrated fertilizer treatment. Grafted tomato plants had greater plant growth than non-grafted plants throughout the growing season. There was no significant difference between fertilizer treatments on nitrate-N concentration in plant tissue or fresh petiole sap; however, grafted plants contained higher levels of nitrate- $\mathrm{N}$ than non-grafted plants. Total and marketable fruit weight and number did not differ due to fertilizer source, but total and marketable fruit weight was higher for grafted plants than for non-grafted plants in 2016. There was no significant effect due to fertilizer source on fruit firmness, water content, $\mathrm{pH}$, titratable acidity, and $\beta$-carotene; however, total soluble solids (TSS) and lycopene content were higher for fruit grown with integrated fertilizer in 2016. Grafting enhanced water content of tomato fruit in 2015, and TSS ( ${ }^{\circ}$ Brix) in 2016.
\end{abstract}

Key words: integrated fertility management, fertilizer, poultry manure, rootstock, lycopene.

Résumé : La tomate (Solanum lycopersicum L.) est une importante culture maraîchère partout dans le monde. Dans de nombreuses régions, on la cultive sous de hauts tunnels ou serres froides. Les auteurs ont examiné les effets de deux régimes de fertilisation, un chimique l'autre intégré (compost de fumier de poulet enrichi d'urée), et du greffage sur la croissance, la concentration de N-nitrate, le rendement et la qualité du fruit des tomates cultivées en serre froide, dans le nord-ouest de l'État de Washington. Le greffage consistait en la greffe de la variété Panzer sur un de trois porte-greffes, en l'occurrence Estamino, Maxifort ou DRO138TX. Un plant non greffé servait de témoin. L'engrais chimique augmente le nombre de feuilles par plant, la taille du plant et la biomasse fraîche cumulative des gourmands élagués comparativement aux plants soumis au régime de fertilisation intégré. Les plants greffés ont affiché une meilleure croissance que ceux qui ne l'étaient pas durant toute la période végétative. Les auteurs n'ont relevé aucune variation importante entre les deux régimes de fertilisation pour ce qui est de la concentration de $\mathrm{N}$-nitrate dans les tissus végétaux ou la sève fraîche des pétioles. Toutefois, la concentration de N-nitrate était plus élevée dans les plants greffés que dans ceux qui ne l'étaient pas. Le poids et le nombre de fruits totaux et de fruits commercialisables ne varie pas avec le type d'engrais, mais le poids des fruits totaux et des fruits commercialisables était plus élevé pour les plants greffés que pour ceux qui ne l'étaient pas, en 2016. Le régime de fertilisation n'a eu aucun effet significatif sur la fermeté du fruit, sa teneur en eau, le $\mathrm{pH}$, l'acidité totale et la concentration de $\beta$-carotène. Néanmoins, la concentration de solides solubles totaux et de lycopène était plus élevée pour les fruits soumis au régime de fertilisation intégré, en 2016. Le greffage a

Received 31 December 2020. Accepted 11 April 2021.

F. Buajaila. Department of Horticulture, College of Agriculture, Omar Al Mukhtar University, PO Box 991, Bayda, Jabal al Akhdar, Libya. J.S. Cowan. Kansas State University, 1712 Claflin Road, 2021 Throckmorton, Manhattan, KS 66506, USA.

D. Inglis and C. Miles. Northwestern Washington Research and Extension Center, Washington State University, 16650 SR 536, Mount Vernon, WA 98273, USA.

L. Carpenter-Boggs. Washington State University, 247 Johnson Hall, PO Box 646420, Pullman, WA 99164-6420, USA.

Corresponding author: Jeremy S. Cowan (email: jscowan@ksu.edu).

(C) 2021 The Author(s). This work is licensed under a Creative Commons Attribution 4.0 International License (CC BY 4.0), which permits unrestricted use, distribution, and reproduction in any medium, provided the original author(s) and source are credited. 
augmenté la teneur en eau du fruit en 2015 et la concentration de solides solubles totaux (degrés Brix) en 2016. [Traduit par la Rédaction]

Mots-clés : fertilisation intégrée, engrais, fumier de poulet, porte-greffe, lycopene.

\section{Introduction}

Tomato (Solanum lycopersicum L.) is an important fresh market vegetable crop grown in the US, with $1225870 \mathrm{t}$ harvested from 38160 ha in 2015 (USDA 2016), and is an important crop for farmers' markets, farm stands, restaurants, and community supported agriculture in many regions, including northwest Washington. The optimum temperature for tomato growth is 18 to $24{ }^{\circ} \mathrm{C}$, and temperatures below $10{ }^{\circ} \mathrm{C}$ negatively affect fruit set (Lovatt et al. 1998). The Skagit Valley is the major vegetable production region in northwestern Washington, and has a 20-yr average temperature of $16{ }^{\circ} \mathrm{C}$ with an average daily minimum of $11^{\circ} \mathrm{C}$ and an average daily maximum of $22{ }^{\circ} \mathrm{C}$ during the summer growing season (June through Sept.; AgWeatherNet 2016). Consequently, tomato production is challenging in this region, and while high tunnels are popular worldwide for tomato production, there has been limited adoption in northwestern Washington (Carey et al. 2009; Lamont 2009). However, high tunnels can provide an environment for successful production of tomato in the area, especially open-ended high tunnels that exclude precipitation, providing protection against late blight (Phytopthora infestans) (Powell et al. 2014). A study in northwest Washington's Skagit Valley found that Tomato cv. Celebrity yielded fruit $15 \mathrm{~d}$ earlier in openended high tunnels, harvest was $20 \mathrm{~d}$ longer, total and marketable fruit weight was 5 to 8-fold greater, and fruit lycopene content was $32 \%$ greater compared with open field production (Miles et al. 2012; Cowan et al. 2014). High tunnels could be used to increase summer production of fresh market tomato in relatively cool conditions of northwest Washington, but more information is needed to optimize production.

High tunnel conditions support intensified crop production requiring increased input applications to maximize yield. Applying large amounts of fertilizers and composts in conjunction with drip irrigation, can elevate soluble salt and nutrient levels in soil that would be leached out with precipitation in the open field (Blomgren and Frisch 2007; Montri and Biernbaum 2009). Elevated soil temperatures in the high tunnel, compared with the open field, may reduce soil moisture and affect soil biological activity and organic matter content (Montri and Biernbaum 2009). Thus, accelerated plant growth and distinct soil conditions, due to elevated temperatures within the high tunnel, creates a need for soil fertility strategies specific to the high tunnel environment. Many fresh market tomato growers in northwest Washington use organic or sustainable production practices, including manure and (or) compost applications to improve soil health and crop yield by enhancing the physical and chemical characteristics of the soil (Stone and Elioff 1998). Maintaining fertility in soil-based high tunnel production systems using organic fertilizers can be a challenge as these fertilizers release nutrients slowly, which can impact crop productivity relative to readily available nutrients in chemical fertilizers (Eghball et al. 2002; Alizadeh et al. 2012; Collins et al. 2013). Use of chemical and organic fertilizers together (integrated fertility management) might provide the benefits of both chemical and organic approaches.

Limited research has been carried out to measure plant growth in response to soil fertility management strategies in high tunnel tomato production. Specifically, little attention has been given to selecting appropriate fertilizer sources and amounts for crop production in protected environments such as high tunnels. In North Logan, Utah, composted poultry manure (CPM) and a polymer-coated slow-release urea were compared for production of tomato cv. Sunbrite grown in a high tunnel system. Both fertilizer sources were applied at three rates $\left(112,168\right.$, and $224 \mathrm{~kg}$ total $\left.\mathrm{N} \cdot \mathrm{ha}^{-1}\right)$ and compared with a control treatment (no fertilizer applied). Pruning was conducted once per week for a total of five to six times after transplanting, and fresh weight of the pruning biomass was recorded. In two out of 3 yr of the study, total pruning fresh biomass was significantly greater for plants grown with urea than with CPM (Reeve and Drost 2012).

Given the relative lack of published research reports on the effects of fertility management in high tunnel tomato production, studies under field conditions may be informative. Demir et al. (2010) investigated the effect of poultry manure (PM) on plant growth and $\mathrm{N}$ leaf concentration of tomato cv. Natura at flowering and at final harvest in a greenhouse study in Turkey. Using three rates of PM (10, 20 and $40 \mathrm{~g} \cdot \mathrm{kg}^{-1}$ soil) and a no PM control, the authors reported that plant dry biomass increased significantly with all three levels of PM as compared with the control, but there was no difference among the PM application rates; additionally, leaf $\mathrm{N}$ was significantly greater for all PM treatments at final harvest (Demir et al. 2010). A study in Turkey found that tomato fruit yield was greater with CPM than with other organic fertilizers (Ormin, Coplex, and composted cattle manure) or chemical fertilizer (Yanar et al. 2011). A field study carried out in Monticello, AR, compared production of several heirloom tomato cultivars using chemical and organic (poultry litter) fertility sources (Francis and Stark 2012). The authors found no differences in marketable fruit number and weight between the two 
production systems; however, the authors found that petiole sap nitrate- $\mathrm{N}$ ranged from 400 to $600 \mathrm{ppm}$ for most samples for both production systems, which was within the sufficiency range for tomato [400-600 ppm (Hochmuth et al. 1991)] (Francis and Stark 2012). Another study carried out in Nigeria compared the effect of PM at four application rates, a chemical fertilizer, and an integrated chemical-PM fertilizer on yield of a local tomato cultivar (Adekiya and Agbede 2009). Leaf N content increased as PM rate increased, and the combination of PM plus chemical fertilizer resulted in higher leaf $\mathrm{N}$ than PM alone. The number of leaves per plant, plant height, and leaf area significantly increased with all study treatments as compared with the control (no fertilizer added), and all growth parameters were greatest for the chemical fertilizer plus PM treatment. The authors reported that the combination of PM plus chemical fertilizer resulted in higher yield than the other treatments (Adekiya and Agbede 2009). It appears clear that both chemical and organic fertilizers can provide tomato plants with required nutrients for optimal growth and yields, but results may vary depending on specific fertilizer programs and production system. Thus, further research is needed to determine the potential efficacy of organic fertilizer sources relative to chemical fertilizers in the context of high tunnels for those growers who prefer organic options.

Grafting has been shown to be a means to avoid biotic and abiotic stress, promote plant growth, and increase crop productivity (Lee 1994; Kubota et al. 2008; Lee et al. 2010). Vegetable grafting is used extensively within protected environment production systems, such as greenhouses and high tunnels. While vegetable grafting has been employed predominantly to manage plant diseases (Peregrine and Bin Ahmad 1982; Lee 1994, 2003, 2007; Paroussi et al. 2007; Sakata et al. 2007; Kubota et al. 2008), it also has been utilized to enhance nutrient uptake and increase nutrient-use efficiency (Ruiz et al. 1997; Santa-Cruz et al. 2002; MartinezBallesta et al. 2010). Grafting provides a rapid response to production constraints and is considered an ecological approach for growers to manage biotic and abiotic stress and provide high-quality tomato fruit (Rivard and Louws 2008). Growers and grafting specialists are attempting to identify rootstocks that are suitable for managing regional issues that affect plant growth and productivity (Kubota et al. 2008; Louws et al. 2010). A study in Magnesia, Greece, compared non-grafted, self-grafted, and grafted tomato in greenhouse (grown in soil) and open field conditions and found no significant effect on plant height under the greenhouse environment due to grafting; however, under open field conditions, plants grafted on 'Heman' rootstocks were significantly taller than non-grafted plants or plants grafted on 'Primavera' at $130 \mathrm{~d}$ after transplanting (Khah et al. 2006). Two open field studies of grafted tomato in northwest Washington, found that grafting 'Cherokee Purple' onto
'Beaufort' or 'Maxifort' rootstocks did not provide any advantages for tomato yield and fruit quality parameters such as firmness, total soluble solids (TSS) and lycopene (Buller et al. 2013); and, 'Stupice' grafted onto six different rootstocks showed no advantage over non-grafted 'Stupice' (Miles et al. 2015). While no differences were found between grafted and non-grafted tomato in open field conditions in these two studies, the dramatic differences in tomato production between high tunnel and open field systems in Washington warrants further investigation to determine the suitability of grafted tomato production in high tunnels generally, and to identify candidate rootstocks for those conditions.

With demand for vegetable grafting increasing each year in the United States, and as tomato is commonly grown in high tunnels, this study may help growers make better-informed decisions about fertilizer source and tomato rootstocks for grafted tomato production in high tunnels in northwest Washington and surrounding regions. Therefore, the goal of the current study was to compare plant growth, nitrate-N uptake, yield, and fruit quality of grafted and non-grafted tomato grown with either chemical fertilizer or an integrated fertilizer treatment (CPM and urea) in high tunnel conditions in northwest Washington.

\section{Materials and Methods}

This study was conducted at Washington State University (WSU) Northwestern Washington Research and Extension Center (NWREC) in Mount Vernon, WA in 2015 and 2016. The field site has Skagit silt loam soil that is a fine-silty, mixed, nonacid, mesic Typic Fluvaquent recently formed of alluvium and volcanic ash (National Resource Conservation Service 2010). Soil at the location contains $2.6 \%$ organic matter, and a $\mathrm{pH}$ value of 6.2 (Ghimire et al. 2018).

\section{High tunnel}

The high tunnel (Oregon Valley Greenhouses Inc., Aurora, OR) was $9.1 \mathrm{~m}$ wide by $29.3 \mathrm{~m}$ long $\left(219 \mathrm{~m}^{2}\right.$ cultivated area), and the peak height was $4.6 \mathrm{~m}$. The tunnel was semi-gabled in shape, with $1.29 \mathrm{~m}$ side walls, roll up sides, zippered end walls, and covered with single layer $0.15 \mathrm{~mm}$ polyethylene. The high tunnel was installed in 2014 and oriented north-to-south - parallel to prevailing winds at the site. The tunnel ends were constructed of woven polyethylene fabric (Clear Span Fabric Structure, South Windsor, CT) and were kept open during the season, to increase airflow to minimize the risk of late blight infection (Powell et al. 2014), except when wind speeds exceeded $5 \mathrm{~m} \cdot \mathrm{s}^{-1}$ (28-31 Aug. 2015, and 7-9 Oct. 2016), when the end was closed temporarily. Side walls were maintained closed during both growing seasons because sufficient ventilation was achieved with open end walls. A tractor was used for soil tillage in the spring to prepare the plots for planting, and in the fall to incorporate plant debris. 


\section{Experimental design}

A split-plot design with four replications per treatment was utilized for the experiment in 2015 and 2016. Fertilizer source was the main plot treatment and included: (1) chemical fertilizer, and (2) integrated fertilizer treatment (CPM plus urea). The subplot treatments were 'Panzer' tomato grafted onto 3 rootstocks: 'Estamino', 'Maxifort', and 'DRO138TX', and non-grafted 'Panzer' (control). Each replicate was a single, flat bed $28.2 \mathrm{~m}$ long. Main plots were $12 \mathrm{~m}$ long and separated by a buffer $1.8 \mathrm{~m}$ long; a buffer $1.2 \mathrm{~m}$ long was also planted at the end of each bed. Subplots were $3 \mathrm{~m}$ long and consisted of five plants grown in a single row. Plants were spaced $0.6 \mathrm{~m}$ in-row, and the beds were spaced $1.9 \mathrm{~m}$, center-to-center. Randomized plot assignments were maintained for both years of this study due to an absence of evidence of soil-borne diseases in 2015, to eliminate potential residual effects from the previous season, and in accord with common practices for high tunnel production in the region.

\section{Fertilizer}

Fertility treatments were calculated to target the application of $112 \mathrm{~N}-74 \mathrm{P}-46 \mathrm{~K}$ while matching the level of Ca applied in each treatment. The target rate was adjusted in 2016 to account for differences in residual soil nutrients. The chemical fertilizer treatment was a mixture of monoammonium phosphate (11N-22.7P-0K), potassium sulfate $(0 \mathrm{~N}-0 \mathrm{P}-41.5 \mathrm{~K})$, urea $(46 \mathrm{~N}-0 \mathrm{P}-0 \mathrm{~K})$, and agricultural lime (36\% Ca) to achieve $112 \mathrm{~N}-74 \mathrm{P}-47 \mathrm{~K}$ and $356 \mathrm{~kg} \cdot \mathrm{ha}^{-1} \mathrm{Ca}$ in 2015 , and $112 \mathrm{~N}-62 \mathrm{P}-43 \mathrm{~K}$ and $288 \mathrm{~kg} \cdot \mathrm{ha}^{-1} \mathrm{Ca}$ in 2016 . Each year CPM was provided by a local farm and was utilized at $2.4 \mathrm{t} \cdot \mathrm{ha}^{-1}$ for both growing seasons accounting for $12 \mathrm{~N}-58 \mathrm{P}-26 \mathrm{~K}$ and $344 \mathrm{~kg} \cdot \mathrm{ha}^{-1}$ Ca in 2015, and 17N-61P-43K and $295 \mathrm{~kg} \cdot \mathrm{ha}^{-1} \mathrm{Ca}$ in 2016. To equalize the $\mathrm{N}$ application rate of the chemical fertilizer treatment, the CPM treatment was amended with urea at $90 \mathrm{~kg} \cdot \mathrm{ha}^{-1} \mathrm{~N}$ each year. We were not able to meet the target rate for $\mathrm{P}$ and $\mathrm{K}$ with CPM in either year without overapplying $\mathrm{Ca}$ and $\mathrm{Na}$. We also opted not to increase urea in the CPM treatment above $90 \mathrm{~kg} \cdot \mathrm{ha}^{-1} \mathrm{~N}$ as we were afraid too much urea would mask any effect of CPM. Two days prior to planting, all fertilizer treatments were added to the center of each bed, and subsequently soil-incorporated by rototilling.

\section{Plant material}

Tomato cv. Panzer (Harris Seeds, Rochester, NY) was selected for this study as it is recommended for greenhouse and high tunnel production due to its resistance to Fusarium wilt (Fusarium oxysporum), Verticillium wilt (Verticillium dahliae), and Fulvia leaf mold (Fulvia fulva), diseases that are all common in high tunnel production systems in northwestern Washington (Reid et al. 2012). 'Panzer' has an indeterminate growth habit, early maturity (76 d), and large, medium-dark-red, round, firm fruit. 'Panzer', 'Estamino', 'Maxifort' and 'DRO138TX' were seeded in the greenhouse on 24 Mar. 2015 and 17 Mar. 2016. Plants were grafted on 9 Apr. 2015 and 4 Apr. 2016 using the splice technique and were healed according to Johnson et al. (2011). After healing, grafted seedlings were transplanted in the field after threat of late frosts past on $30 \mathrm{Apr} .2015$ and 29 Apr. 2016. Plants were trellised using a modified Florida Weave training system (Kelbert et al. 1966). Plants were pruned by pinching suckers to maintain a single leader, and leaves that overlapped neighboring plants or touched the soil were also pruned.

\section{Irrigation}

Irrigation was delivered by means of a single drip tape per row (emitter spacing $20 \mathrm{~cm}$, flow rate $77 \mathrm{~L} \cdot \mathrm{h}^{-1}$ per $31 \mathrm{~m}$, Rivulis, Israel) for 90-120 min per application up to three times a week, the system provided 397 and $368 \mathrm{~mm}$ for 2015 and 2016, respectively, according to tomato plant growth stage, soil moisture conditions, or crop symptoms like physiological leaf roll or temporary wilt that developed when temperatures exceeded $27^{\circ} \mathrm{C}$.

\section{Disease and weed management}

To protect against late blight, copper hydroxide (Nu-cop 50 DF; Albaugh, LLC, Ankeny, IA) was applied at $1.12 \mathrm{~kg} \cdot \mathrm{ha}^{-1}$ on 12 June in 2015, and 15 June in 2016, using a solo backpack sprayer. Weeds around the plants and between the rows were controlled by hand weeding as needed.

\section{Climate measurements}

Air and soil temperature (1.5 m height, and 5 and $20 \mathrm{~cm}$ depth, respectively), relative humidity (RH), soil water content and leaf wetness were measured (Hobo U30-NRC weather station, Onset Computer, Bourne, MA) at every $1 \mathrm{~h}$ with the respective sensors installed in the center of the high tunnel during the two growing seasons. Growing degree days at base temperature of $10{ }^{\circ} \mathrm{C}\left(\mathrm{GDD}_{10}\right)(\mathrm{McMaster}$ and Wilhelm 1997) were calculated from the daily minimum $\left(T_{\min }\right)$ and maximum $\left(T_{\max }\right)$ temperatures utilizing the following equation

$$
\mathrm{GDD}_{10}=\Sigma \max \left[\left(\mathrm{T}_{\max }+\mathrm{T}_{\min }\right) / 2-10,0\right]
$$

\section{Plant growth and nitrate content}

The number of leaves per plant was recorded at $21 \mathrm{~d}$ after transplanting (DAT), and every $3 \mathrm{wk}$ thereafter throughout the growing season for a total of 4 measurements each year, with the final measurement at 82 DAT in 2015 (21 July 2015) and at 83 DAT in 2016 (22 July 2016). Plant height was also measured at 21 DAT, and every 3 wk for a total of 5 measurements each year, with the final measurement at 104 DAT in 2015 (12 Aug. 2015) and at 108 DAT in 2016 (15 Aug. 2016). Pruning was initiated 5 wk after transplanting, at 35 DAT in 2015 (4 June 2015) and 39 DAT in 2016 (7 June 2016), and occurred once per week as needed thereafter throughout the growing 
season for a total of 9 times each year with the final pruning at 116 DAT in 2015 (24 Aug. 2015) and 138 DAT in 2016 (14 Sept. 2016). Fresh pruning biomass was measured for each subplot following each pruning (Kirda et al. 2004; Reeve and Drost 2012).

At 5, 7, 9, and 11 wk after transplanting each year, nitrate-N was measured in leaf tissue and fresh petiole sap by sampling the fifth or sixth youngest fully mature leaf from the top of each plant in each subplot (five leaves per subplot). Immediately after collection, leaves were placed in a plastic bag, and the bag was placed on ice in an insulated cooler. After all subplots were sampled, leaves were brought to the laboratory. Petioles were separated from the leaf tissue using a razor blade. The petiole sap was extracted using a mortar and pestle, and four to five drops of sap from each replicate subplot were placed on the sensor of a Cardy meter (Horiba Scientific, Edison, NJ) and the amount of nitrate (ppm) recorded (Hochmuth 1994; Locascio et al. 1997; Andersen et al. 1999). For leaf tissue nitrate- $\mathrm{N}\left(\mathrm{mg} \cdot \mathrm{kg}^{-1}\right)$, samples were dried at $65-70{ }^{\circ} \mathrm{C}$ for $3 \mathrm{~d}$, then ground (Perten Instrument, Hagersten, Sweden), and $0.5 \mathrm{~g}$ per sample were sent to a chemical laboratory for analysis using the Kjeldahl method (Kjeldahl 1883).

\section{Fruit measurements}

Fruits were harvested when at least 75\% ripe [corresponding to the "light red" ripeness stage (USDA 1975)], once each week starting at $82 \mathrm{~d}$ after transplanting (DAT) in 2015 (21 July 2015), and 98 DAT in 2016 (5 Aug. 2016), with final harvest after the first killing frost 179 DAT in 2015 (26 Oct. 2015) and 178 DAT in 2016 (24 Oct. 2016). At each harvest, weight and number of both marketable and unmarketable (total) fruit were recorded. Unmarketable fruit were classified according to the main reason for unmarketability, then discarded. Sunscald, cracking, bruising, catfacing, and zippering were the main defects causing tomato fruit in this study to be classified unmarketable.

Two to three marketable fruit, with total weight of 250-500 g, were randomly selected from each subplot at 88, 95, 102 and 109 DAT in 2015 (27 July, 3, 10 and 17 Aug. 2015), and 105, 117, 123 and 139 DAT in 2016 (12, 24, 30 Aug. and 15 Sept. 2016), for a total of four sampling times per subplot each year. Fruits were allowed to fully ripen in the laboratory for $3-7 \mathrm{~d}$ at room temperature $\left(23^{\circ} \mathrm{C}\right)$. Red-ripe fruit were rinsed in a water bath for $30 \mathrm{~s}$, gently sprayed with cool water, then set on a towel and dried gently so as to not bruise. Fruit were cut in half about $3 \mathrm{~mm}$ from center (equator) and a $6 \mathrm{~mm}$ slice was cut from the larger segment. The slice was reserved for firmness testing while one of the halves was placed in a drying tray to measure water content and the other half was placed in the blender for other fruit quality measurements.

\section{Firmness}

Each tomato slice (6 $\mathrm{mm}$ thick) was placed below a penetrometer (L-500, Ametek, Hunter Spring Division, Hatfield, PA), then the tip (8 $\mathrm{mm}$ diameter, flat) was centered over the outer pericarp between septa and gradually lowered until it punctured the pericarp of the slice. The value was recorded to the nearest $5 \mathrm{gf}$ with normal rounding, and the slice was rotated and the process repeated until four locations were measured. The average per subplot was calculated for each sample time and units of gram force were converted to Newtons by multiplying the average gram force by $9.807 \times 10^{-3}$.

\section{Water content}

Fresh weight (FW) of each fruit half was recorded, fruit were then placed in a drying tray and dried in the oven for $48 \mathrm{~h}$ at $80^{\circ} \mathrm{C}$ and dry weight (DW) was recorded. Percent water content was calculated as

$$
[(\mathrm{FW}-\mathrm{DW}) / \mathrm{FW}] \times 100
$$

\section{Fruit homogenate}

For each subplot, the second tomato half and the slice used for the firmness measurement were placed into a blender (Oster 6832; Jarden Consumer Solution, Boca Raton, FL) and homogenized at highest speed for $2 \mathrm{~min}$. Fruit homogenate was used for total soluble solids, $\mathrm{pH}$, titratable acidity, lycopene and $\beta$-carotene measurements.

\section{Total soluble solids}

One $50 \mathrm{~mL}$ centrifuge tube was filled completely with homogenate and centrifuged for $10 \mathrm{~min}$ at 3000 rpm (Beckman TJ-6, Beckman Instruments, Inc., Palo Alto, CA). Using a transfer pipette, 3-4 drops of tomato juice from the middle layer as separated by centrifugation were placed onto the clean window of a refractometer (Misco, Cleveland, $\mathrm{OH}$ ) and the total soluble solids (TSS, measured as ${ }^{\circ} \mathrm{Brix}$ ) was measured and recorded.

\section{pH and titratable acidity}

Two $50 \mathrm{~mL}$ centrifuge tubes were filled completely with homogenate and centrifuged for $10 \mathrm{~min}$ at 3000 rpm (Beckman TJ-6, Beckman Instruments, Inc., Palo Alto, CA). For each sample, $30-40 \mathrm{~mL}$ of tomato juice extracted from the middle layer was placed into a $50 \mathrm{~mL}$ beaker and the $\mathrm{pH}$ value was measured and recorded (Beckman $\varnothing 32 \mathrm{pH}$ meter; Beckman Instruments, Inc., Fullerton, CA). Next, $4 \mathrm{~mL}$ of the extracted tomato juice was combined with $50 \mathrm{~mL}$ de-ionized water and manually titrated to $\mathrm{pH} 8.1 \pm 0.1$ with $0.2 \mathrm{~N} \mathrm{NaOH}$. The value of the titratable acidity was calculated by the following equation

(3) $\mathrm{TA}(w / v)=\left(N \times V_{1} \times\right.$ Eq.wt $) /\left(V_{2} \times 1000 \mathrm{mg} / \mathrm{g}\right) \times 100$ 
In this equation, $N$ is the normality of the titrant $=0.2 ; V_{1}$ is the volume of titrant $(\mathrm{mL})$; Eq. $\mathrm{wt}$. $=\mathrm{mg} / \mathrm{mEq}$ of the predominant acid, in this case citric acid (CA) $=64 \mathrm{mg} / \mathrm{mEq}$; and $V_{2}$ is the volume of the sample $(\mathrm{mL})=4 \mathrm{~mL}$ in this case (Sadler and Murphy 2003).

\section{Lycopene and $\beta$-carotene}

One gram of well-blended homogenate was placed in a micro centrifuge tube, then tubes were immediately placed in the freezer $\left(-30^{\circ} \mathrm{C}\right)$ for a minimum of $2 \mathrm{wk}$. Samples were removed from the freezer, thawed for approximately $3 \mathrm{~h}$, transferred to a $50 \mathrm{~mL}$ centrifuge tube, wrapped with aluminum foil to prevent light degradation, and $16 \mathrm{~mL}$ of cold 2:3 acetone:hexane reagent was added. The cap was closed tightly, and the tube was placed in the freezer $\left(-30^{\circ} \mathrm{C}\right)$ for $1 \mathrm{~h}$ to dissolve all the carotenoid. The tubes were removed from the freezer and placed at room temperature $\left(23^{\circ} \mathrm{C}\right)$ for $5 \mathrm{~min}$ to ensure separation into two specific layers; the upper layer was collected for analysis. Lycopene and $\beta$-carotene were measured spectrophotometrically (Navarro et al. 2006). The spectrophotometer (Beckman DU-640 spectrophotometer, Beckman Instruments, Inc., Fullerton, CA) was calibrated to zero using $3 \mathrm{~mL}$ of cold hexane solution and absorbance was measured at 663, 645, 505, and $453 \mathrm{~nm}\left(A_{663}, A_{645}, A_{505}, A_{453}\right.$, respectively). Lycopene $[\mu \mathrm{g} / 100 \mathrm{~g}$ fruit (fresh weight basis)] was determined by the following formula

$$
\begin{aligned}
{\left[\left(-0.0458 \times A_{663}\right)+\right.} & \left(0.204 \times A_{645}\right)+\left(0.372 \times A_{505}\right) \\
& \left.-\left(0.0806 \times A_{453}\right)\right] \times(1000 / 0.1042)
\end{aligned}
$$

$\beta$-carotene ( $\mu \mathrm{g} / 100 \mathrm{~g}$ fruit) was determined by the following formula

$$
\begin{aligned}
{\left[\left(0.216 \times A_{663}\right)-\left(1.220 \times A_{645}\right)-\left(0.304 \times A_{505}\right)\right.} \\
\left.+\left(0.452 \times A_{453}\right)\right] \times(1000 / 0.1042)
\end{aligned}
$$

\section{Data analysis}

All data were analyzed in JMP (version 11.0 for Windows; SAS Institute Inc., Cary, NC). Homogeneity of variances was assessed using Levene's test $(\alpha=0.05)$, and normality by using Shapiro-Wilk test $(W>0.80)$. Some data were transformed before analysis to meet the assumptions of normality and equality of variance by using square root or log transformation. Factors that were transformed for analysis are indicated in the tables the analyses are presented in. Treatment means were compared using least squares means (LSM) Student's test at $\alpha=0.05$. Due to significant interactions between year and sampling time and the main effects, all analyses were run independently for each year and sampling time.

\section{Results}

\section{Climate conditions}

The average air temperature in the high tunnel was $1.2{ }^{\circ} \mathrm{C}$ higher than the adjacent open field (Table 1).
The average accumulated growing degree days $\left(\mathrm{GDD}_{10}\right)$ in the high tunnel from May to Oct. was 1394 in 2015 and 1238 in 2016, compared with 1058 and 971 in the open field in these years, respectively. This represents a $30 \%$ gain in $\mathrm{GDD}_{10}$ in the high tunnel on average. The average soil temperature in the high tunnel at 5 and $20 \mathrm{~cm}$ depth was 18.9 and $18.8^{\circ} \mathrm{C}$, respectively, each year, which was $1.4^{\circ} \mathrm{C}$ greater on average than in the open field (17.2 and $16.7^{\circ} \mathrm{C}$, respectively).

\section{Plant growth}

The total number of leaves per plant was not affected by fertilizer, rootstock, or year, or the interactions among those factors $(P>0.05)$ except between fertilizer and year at the first sampling time (21 DAT each year) $(P=0.04)$. When analyzed separately by year and sampling time, the number of leaves was greater when plants were fertilized with chemical fertilizer than with integrated fertilizer both early and mid-season (21 and 42 DAT, respectively) in 2015, and mid-season (45 DAT) in 2016 (Table 2). There was no effect on number of leaves per plant due to grafting at any sampling time in either year.

Plant height differed due to fertilizer at the first and second sampling times $(P=0.04$ and $P=0.02$, respectively), due to rootstock at the second, third and fourth sampling times $(P=0.05, P=0.01$ and $P<0.0001$, respectively), and due to year at the second, third and fifth sampling times $(P=0.02, P=0.0008$ and $P=0.02$, respectively); a significant interaction between rootstock and year was detected at all but the fifth sampling time $(P<0.05)$. When analysed separately by year and sampling time, plant height was greater for plants grown with conventional fertilizer than with integrated fertilizer at 21 and 42 DAT in 2015, and on all but the last sampling date (107 DAT) in 2016 (Table 3). There was no effect on plant height due to grafting with the three rootstocks in 2015, but in 2016 grafted plants were taller than nongrafted plants on all but the last sampling date, and 'Estamino' tended to have greater plant height at all sampling dates.

Cumulative fresh biomass of pruned suckers differed due to fertilizer, rootstock, year, and sampling time $(P<0.0001, P=0.0003, P=0.008$, and $P<0.0001$, respectively). When analyzed separately by sampling time, cumulative fresh biomass of pruned suckers differed due to fertilizer at two sampling times, and due to rootstock and year at most sampling times, and significant interactions were detected among fertilizer and rootstock or fertilizer and year at some sampling dates, and no other interaction was found (Table 4). Cumulative fresh biomass of pruned suckers was greater with chemical fertilizer than with integrated fertilizer at all sampling times in both years $(P \leq 0.01)$ (Fig. 1). Except at 35 DAT in $2015(P=0.21)$, cumulative fresh biomass of pruned suckers was greater for grafted rootstocks than non-grafted plants $(P \leq 0.01)$; 
Table 1. Environmental conditions in the open field (OF) and high tunnel (HT) at Washington State University Mount Vernon Northwestern Washington Research and Extension Center during the 2015 and 2016 summer growing seasons.

\begin{tabular}{|c|c|c|c|c|c|c|c|c|c|c|c|c|}
\hline \multirow[b]{3}{*}{ Month } & \multicolumn{6}{|l|}{2015} & \multicolumn{6}{|l|}{2016} \\
\hline & \multirow{2}{*}{$\begin{array}{l}\mathrm{OF}^{a} \\
\text { Avg } \\
{ }^{\circ} \mathrm{C}\end{array}$} & \multicolumn{5}{|l|}{$\mathrm{HT}^{b}$} & \multirow{2}{*}{$\begin{array}{l}\frac{\mathrm{OF}}{} \\
\text { Avg } \\
{ }^{\circ} \mathrm{C}\end{array}$} & \multicolumn{5}{|l|}{$\mathrm{HT}$} \\
\hline & & $\begin{array}{l}\text { Min } \\
{ }^{\circ} \mathrm{C}\end{array}$ & $\begin{array}{l}\text { Avg } \\
{ }^{\circ} \mathrm{C}\end{array}$ & $\begin{array}{l}\text { Max } \\
{ }^{\circ} \mathrm{C}\end{array}$ & $\begin{array}{l}\text { Avg } \\
\% R H\end{array}$ & $\begin{array}{l}\text { Soil } \\
\text { moisture } \\
\mathrm{m}^{3} / \mathrm{m}^{3}\end{array}$ & & $\begin{array}{l}\text { Min } \\
{ }^{\circ} \mathrm{C}\end{array}$ & $\begin{array}{l}\text { Avg } \\
{ }^{\circ} \mathrm{C}\end{array}$ & $\begin{array}{l}\text { Max } \\
{ }^{\circ} \mathrm{C}\end{array}$ & $\begin{array}{l}\text { Avg } \\
\% R H\end{array}$ & $\begin{array}{l}\text { Soil } \\
\text { moisture } \\
\mathrm{m}^{3} / \mathrm{m}^{3} \\
\end{array}$ \\
\hline May & 13.5 & 9.3 & 15.4 & 23.1 & 83 & 0.29 & 13.8 & 9.2 & 14.7 & 21.4 & 79 & 0.25 \\
\hline June & 17.1 & 11.6 & 19.1 & 27.6 & 73 & 0.25 & 15.3 & 11.2 & 16.5 & 23.3 & 80 & 0.25 \\
\hline July & 18.9 & 13.4 & 20.5 & 28.8 & 74 & 0.24 & 17.3 & 12.9 & 18.9 & 26.2 & 79 & 0.24 \\
\hline August & 17.9 & 12.7 & 19.4 & 27.4 & 79 & 0.23 & 17.6 & 12.2 & 18.8 & 26.9 & 80 & 0.24 \\
\hline September & 14.0 & 9.7 & 14.8 & 21.2 & 88 & 0.22 & 14.2 & 9.9 & 15.1 & 21.4 & 88 & 0.24 \\
\hline October & 12.5 & 8.5 & 13.0 & 18.8 & 95 & 0.21 & 12.0 & 8.8 & 12.6 & 18.9 & 94 & 0.23 \\
\hline Average & 15.7 & 10.9 & 17.0 & 24.5 & 83 & 0.29 & 15.0 & 10.7 & 16.1 & 23.0 & 79 & 0.25 \\
\hline
\end{tabular}

${ }^{a}$ Data collected using WSU AgWeatherNet weather station located at WSU Mount Vernon NWREC, approximately 93 m from the experimental site, from May to October 2015 and 2016.

${ }^{b}$ Data collected using Hobo U30-NRC weather station (Onset Computer, Bourne, MA, USA) $1.5 \mathrm{~m}$ above the soil surface in the center of the high tunnel during tomato growing season, from May to October 2015 and 2016.

and, no differences in cumulative fresh biomass of pruned suckers were detected between rootstocks of grafted plants.

\section{Plant nitrogen}

Nitrate- $\mathrm{N}$ in plant tissue differed due to fertilizer $(P=0.049) 7 \mathrm{wk}$ after transplanting, due to rootstock at 7 and 9 wk after transplanting $(P=0.001, P=0.004)$, and due to year at 7,9 , and 11 wk after transplanting $(P<0.0001, P<0.0001$, and $P=0.03$, respectively). There was a significant interaction between fertilizer and rootstock $(P=0.03)$ at $5 \mathrm{wk}$ after transplanting and between rootstock and year $(P=0.01)$ at 9 wk after transplanting, but no other interactions were significant. When analysed separately by year and sampling time, there was no effect on nitrate- $\mathrm{N}$ in plant tissue due to fertilizer source at any sampling time in either year. There was also no effect on nitrate- $\mathrm{N}$ in plant tissue due to grafting with the three rootstocks in 2015; however, in 2016 all grafted plants had higher nitrate-N in plant tissue than non-grafted plants at 7 and 9 wk after transplanting, except for 'DRO138TX' at 9 wk (Table 5).

Nitrate- $\mathrm{N}$ in fresh petiole sap was different due to rootstock at all sampling times $(P \leq 0.003)$ except $9 \mathrm{wk}$ after transplanting $(P=0.11)$, and due to year at 5 and $9 \mathrm{wk}$ after transplanting $(P=0.0003$ and $P<0.0001$, respectively). There was a significant interaction between fertilizer and year at 5 and $7 \mathrm{wk}$ after transplanting $(P=0.03$ and $P=0.049$, respectively) and between all main factors 9 wk after transplanting $(P=0.03)$. When analyzed separately by year and sampling time, fertilizer source did not affect nitrate-N content of fresh petiole sap at any sampling time in either year (Table 5). A significant increase in nitrate- $\mathrm{N}$ of fresh petiole sap was observed 5 wk after transplanting as a result of grafting with
'Estamino' in 2015, and at 7 wk after transplanting in 2016; additionally, nitrate- $\mathrm{N}$ of fresh petiole sap was greater for all three rootstocks at 9 and 11 wk after transplanting in 2016.

\section{Fruit yield}

Total and marketable fruit number and weight were not affected by fertilizer source $(P>0.05)$. Total and marketable fruit number differed due to rootstock $(P=0.007$ and $P=0.02$, respectively). Total and marketable fruit number and weight also differed due to the year (all $P<0.0001)$. No interactions between the main factors were significant for total and marketable fruit number and weight. When analysed separately by year, total and marketable fruit number and weight were not affected by fertilizer source either year (Table 6). In 2015, there was no difference in total and marketable fruit weight due to grafting; however, the number of total and marketable fruit was greatest for non-grafted 'Panzer', and lower for grafted 'Maxifort' (Fig. 2). In 2016, the number of total and marketable tomato fruit did not differ due to grafting, but the weight of total and marketable fruit was greater for grafted plants as compared with non-grafted plants. The first fruit harvest was at 82 and 98 DAT in 2015 and 2016, respectively, and the last harvest was 179 and 178 DAT in 2015 and 2016, respectively, and harvest did not occur earlier or later due to fertilizer source or the use of grafted plants either year. Although, the non-grafted plants had a higher number of fruits at the first and last harvests in 2015, and at the first harvest in 2016. The most prevalent cause of unmarketability in both growing seasons was sunscald, accounting for $43 \%$ and $58 \%$ of unmarketable fruit in 2015 and 2016, respectively. There was a greater incidence of bruising and cracking in 2015 compared with 2016 (data not shown). 
Table 2. Mean number of leaves per plant of 'Panzer' tomato grown with two fertilizer treatments and four grafting treatments in a high tunnel at Washington State University Mount Vernon Northwestern Washington Research and Extension Center.

Number of leaves per plant ${ }^{a}$ Days after transplanting (DAT)

\begin{tabular}{lllll}
\hline 2015 & & & & \\
\hline Fertilizer $^{b}$ & 21 & 42 & 62 & 83 \\
\hline Chemical & 8.7 & 10.2 & 16.8 & 20.1 \\
Integrated & 8.2 & 9.7 & 16.9 & 20.0 \\
\hline P value & 0.02 & 0.02 & 0.77 & 0.82 \\
\hline Rootstock & & & & \\
\hline DRO 138 & 8.5 & 9.9 & 16.7 & 19.7 \\
Estamino & 8.2 & 9.9 & 16.7 & 19.6 \\
Maxifort & 8.6 & 10.1 & 16.9 & 20.2 \\
Nongrafted & 8.6 & 10.1 & 17.1 & 20.8 \\
\hline P value & 0.57 & 0.81 & 0.46 & 0.24 \\
\hline
\end{tabular}

2016

\begin{tabular}{lllll}
\hline Fertilizer & 21 & 45 & 64 & 84 \\
\hline Chemical & 8.4 & 10.1 & 16.8 & 20.4 \\
Integrated & 8.4 & 9.5 & 17.2 & 20.6 \\
\hline$P$ value & 0.96 & 0.01 & 0.38 & 0.65
\end{tabular}

Rootstock

\begin{tabular}{lllll}
\hline DRO 138 & 8.5 & 9.9 & 16.9 & 20.2 \\
Estamino & 8.2 & 9.7 & 17.1 & 20.0 \\
Maxifort & 8.4 & 9.6 & 16.8 & 20.6 \\
Nongrafted & 8.5 & 9.9 & 17.1 & 21.2 \\
\hline$P$ value & 0.56 & 0.77 & 0.93 & 0.41 \\
\hline
\end{tabular}

Note: Data were collected at 21, 42, 62 and 83 days after transplanting (DAT) in 2015, and 21, 45, 64 and 84 DAT in 2016 during the summer growing seasons.

${ }^{a}$ All data were subjected to analysis of variance using ANOVA in JMP (version $\mathbf{1 1 . 0}$ for Windows; SAS Institute Inc., Cary, NC, USA).

${ }^{b}$ Chemical fertilizer was applied at $112 \mathrm{~N}-74 \mathrm{P}-47 \mathrm{~K}$ and $356 \mathrm{Ca} \mathrm{kg} \cdot \mathrm{ha}^{-1}$ in 2015, and $112 \mathrm{~N}-62 \mathrm{P}-43 \mathrm{~K}$ and $288 \mathrm{Ca} \mathrm{kg} \cdot \mathrm{ha}^{-1}$ in 2016 . Integrated fertilizer was composted poultry manure (nutrient application rates were $12 \mathrm{~N}-58 \mathrm{P}-26 \mathrm{~K}$ and $344 \mathrm{Ca} \mathrm{kg} \cdot \mathrm{ha}^{-1}$ in 2015 , and $17 \mathrm{~N}-61 \mathrm{P}-43 \mathrm{~K}$ and $295 \mathrm{Ca} \mathrm{kg} \cdot \mathrm{ha}^{-1}$ in 2016) plus nitrogen fertilizer $\left(90 \mathrm{~kg} \cdot \mathrm{ha}^{-1} \mathrm{~N}\right)$.

\section{Marketable fruit quality}

Lycopene content differed due to fertilizer source $(P=0.0005)$, firmness, juice content and lycopene content differed due to rootstock $(P=0.05, P=0.006$ and $P=0.01$, respectively), and firmness, TSS, $\mathrm{pH}$ and titratable acidity differed due to year $(P<0.0001, P<0.0001$, $P=0.01$ and $P<0.0001$, respectively), and there was no other effect on fruit quality parameters due to the main factors detected in this study, significant interactions between fertilizer and year and between rootstock and year were detected for TSS content $(P=0.0009$ and $P<0.0001$, respectively), but no other significant interactions were found. When analysed separately by year, fruit quality parameters were not affected by fertilizer source in 2015, but TSS and lycopene content were greater for integrated fertilizer than chemical fertilizer in 2016. Grafting with each of three rootstocks enhanced fruit water content in 2015 and TSS in 2016, though no differences in water content and TSS were detected among the grafted rootstocks (Table 7).

\section{Discussion}

Application of a chemical fertilizer increased growth of tomato plants (number of leaves per plant, plant height, and cumulative pruning fresh biomass) compared with plants grown with an integrated fertilizer treatment, especially early in the growing season. The increased growth of tomato plants in the current study with chemical fertilizer relative to plant growth under the integrated fertilizer regimen was in contrast to the findings of Adekiya and Agbede (2009), where all tomato growth parameters including number of leaves per plant and plant height were greatest for chemical fertilizer with PM. Results of the current study are similar to Reeve and Drost (2012) who reported in two out of $3 \mathrm{yr}$ total pruning fresh biomass was significantly higher for plants grown with chemical fertilizer than with CPM. In the current study, plant growth measures differed between fertilizer treatments early in each season, and were similar later in the season, except for cumulative pruning fresh biomass which was greater with chemical fertilizer throughout the growing season. The greater early plant growth using chemical fertilizer relative to the integrated treatment in the current study is likely due to the more readily available nutrients from the chemical fertilizer compared with the integrated fertilizer treatment (Isah et al. 2014). Adding a source of readily available nutrients early in the season may ensure sufficient plant nutrition until organic sources become available to plants later in the season.

Results of the current study also indicate that grafted tomato plants tended to have greater plant growth than non-grafted plants throughout the growing season. For example, 'Panzer' grafted on 'Estamino' tended to have the greatest plant height throughout the growing season. These results differ from Khah et al. (2006) who found no significant effect due to grafting on plant height in a greenhouse environment (average daily temperature was $27.7^{\circ} \mathrm{C}$ ). However, those authors also found that under open field conditions (average daily temperatures was $23.5^{\circ} \mathrm{C}$ ), plants grafted with 'Heman' were significantly taller than non-grafted plants or plants grafted with 'Primavera' at the end of the growing season. In the current study, the average daily temperature 
Table 3. Mean plant height $(\mathrm{cm})$ of 'Panzer' tomato grown with two fertilizer treatments and four grafting treatments in a high tunnel at Washington State University Mount Vernon Northwestern Washington Research and Extension Center.

\begin{tabular}{|c|c|c|c|c|c|}
\hline \multirow[b]{2}{*}{2015} & \multicolumn{5}{|c|}{$\begin{array}{l}\text { Plant height }{ }^{a}(\mathrm{~cm}) \\
\text { Days after transplanting (DAT) }\end{array}$} \\
\hline & & & & & \\
\hline Fertilizer $^{b}$ & 21 & 42 & 62 & 83 & 104 \\
\hline Chemical & 44.5 & 70.8 & 120.5 & 173.0 & 226.6 \\
\hline Integrated & 37.0 & 61.8 & 117.2 & 170.3 & 229.7 \\
\hline$P$ value & 0.02 & 0.01 & 0.35 & 0.44 & 0.55 \\
\hline \multicolumn{6}{|l|}{ Rootstock } \\
\hline DRO 138 & 37.8 & 63.9 & 113.0 & 167.6 & 232.2 \\
\hline Estamino & 38.7 & 64.4 & 119.6 & 173.9 & 225.9 \\
\hline Maxifort & 43.1 & 68.1 & 118.8 & 173.7 & 226.8 \\
\hline Nongrafted & 43.4 & 68.8 & 124.1 & 171.4 & 227.7 \\
\hline$P$ values & 0.46 & 0.66 & 0.18 & 0.54 & 0.82 \\
\hline \multicolumn{6}{|l|}{2016} \\
\hline Fertilizer & 21 & 42 & 63 & 84 & 107 \\
\hline Chemical & 44.7 & 66.7 & 113.9 & 170.6 & 236.3 \\
\hline Integrated & 39.1 & 56.9 & 106.8 & 163.5 & 233.5 \\
\hline$P$ value & $<0.0001$ & $<0.0001$ & 0.01 & 0.05 & 0.39 \\
\hline \multicolumn{6}{|l|}{ Rootstock } \\
\hline DRO 138 & $42.0 \mathrm{~b}$ & $63.4 \mathrm{~b}$ & 113.1b & $174.5 \mathrm{a}$ & 235.3 \\
\hline Estamino & $47.5 \mathrm{a}$ & $70.8 \mathrm{a}$ & 121.1a & 177.5a & 242.2 \\
\hline Maxifort & $43.0 \mathrm{~b}$ & $61.7 \mathrm{~b}$ & 113.5ab & $171.6 \mathrm{a}$ & 233.1 \\
\hline Nongrafted & $35.0 \mathrm{c}$ & $51.2 \mathrm{c}$ & $93.8 \mathrm{c}$ & $144.6 \mathrm{~b}$ & 229.0 \\
\hline$P$ values & $<0.0001$ & $<0.0001$ & $<0.0001$ & $<0.0001$ & 0.052 \\
\hline
\end{tabular}

Note: Data were collected at 21, 42, 62, 83 and 104 days after transplanting (DAT) in 2015, and 21, 42, 63, 84 and 107 DAT in 2016 during the summer growing seasons. Means followed by the same letter within sampling date are not significantly different at $P<0.05$.

${ }^{a}$ All data were subjected to analysis of variance using ANOVA in JMP (version 11.0 for Windows; SAS Institute Inc., Cary, NC, USA).

${ }^{b}$ Chemical fertilizer was applied at $112 \mathrm{~N}-74 \mathrm{P}-47 \mathrm{~K}$ and $356 \mathrm{Ca} \mathrm{kg} \cdot \mathrm{ha}^{-1}$ in 2015 , and $112 \mathrm{~N}-62 \mathrm{P}-43 \mathrm{~K}$ and $288 \mathrm{Ca} \mathrm{kg} \cdot \mathrm{ha}^{-1}$ in 2016 . Integrated fertilizer was composted poultry manure (nutrient application rates were $12 \mathrm{~N}-58 \mathrm{P}-26 \mathrm{~K}$ and $344 \mathrm{Ca} \mathrm{kg} \cdot \mathrm{ha}^{-1}$ in 2015 , and $17 \mathrm{~N}-61 \mathrm{P}-43 \mathrm{~K}$ and $295 \mathrm{Ca} \mathrm{kg} \cdot \mathrm{ha}^{-1}$ in 2016) plus nitrogen fertilizer $\left(90 \mathrm{~kg} \cdot \mathrm{ha}^{-1} \mathrm{~N}\right)$.

was $16.6^{\circ} \mathrm{C}$ in the high tunnel, which is less than optimal for tomato plant growth (optimal is $18-24^{\circ} \mathrm{C}$ ). Growth of grafted plants in the current study tended to be significantly greater than non-grafted plants. This result suggests that grafting onto select rootstocks can improve plant growth in sub-optimal conditions, perhaps by enhancing absorption and translocation of nutrients (Han et al. 2009; Nawaz et al. 2016; Ceylan et al. 2018). Further research is needed to better understand the relationship between environmental conditions and growth of grafted plants. Regardless, it appears that. rootstock selection may be a valuable consideration for developing an annual management plan and addressing long-term soil fertility for tomato production in regions with low temperatures during the growing season, as in northwest Washington, and also warrants further investigation.

Fertilizer source had no significant effect on nitrate-N in plant tissue or fresh petiole sap in this study. This finding differs from Adekiya and Agbede (2009) who found 
Table 4. Overall $P$ values from analysis of variance of the main factors (fertilizer, rootstock, and year) and their interactions for cumulative fresh biomass of pruned suckers (g.plant ${ }^{-1}$ ) of 'Panzer' tomato grown with two fertilizer treatments and four grafting treatments in a high tunnel at Washington State University Mount Vernon Northwestern Washington Research and Extension Center in 2015 and 2016.

\begin{tabular}{|c|c|c|c|c|c|c|c|c|c|}
\hline & \multicolumn{9}{|c|}{$P$ values ${ }^{a}$ for sampling time ${ }^{b}$} \\
\hline & 1 & 2 & 3 & 4 & 5 & 6 & 7 & 8 & 9 \\
\hline Fertilizer & $<0.0001$ & 0.14 & 0.16 & 0.13 & 0.12 & 0.12 & 0.08 & 0.05 & 0.07 \\
\hline Rootstock & 0.002 & 0.91 & 0.004 & $<0.0001$ & $<0.0001$ & $<0.0001$ & $<0.0001$ & $<0.0001$ & $<0.0001$ \\
\hline Year & 0.001 & $<0.0001$ & 0.0005 & 0.001 & $<0.0001$ & $<0.0001$ & $<0.0001$ & 0.003 & 0.001 \\
\hline Fertilizer $\times$ Rootstock & 0.50 & 0.99 & 0.59 & 0.01 & 0.01 & 0.06 & 0.003 & 0.01 & 0.07 \\
\hline Fertilizer $\times$ Year & 0.002 & 0.0002 & 0.02 & 0.86 & 0.50 & 0.66 & 0.03 & 0.73 & 0.09 \\
\hline Rootstock $\times$ Year & 0.50 & 0.85 & 0.40 & 0.84 & 0.18 & 0.46 & 0.06 & 0.72 & 0.62 \\
\hline $\begin{array}{l}\text { Fertilizer } \times \\
\quad \text { Rootstock } \times \text { Year }\end{array}$ & 0.55 & 0.97 & 0.60 & 0.99 & 0.91 & 0.97 & 0.76 & 0.94 & 0.84 \\
\hline
\end{tabular}

${ }^{a}$ All data were subjected to analysis of variance using ANOVA in JMP (version 11.0 for Windows; SAS Institute Inc., Cary, NC, USA).

${ }^{b} 1$ : at 35 days after transplanting (DAT) in 2015 and 39 DAT 2016; 2: 42 DAT in 2015 and 52 DAT in 2016; 3: 53 DAT in 2015 and 60 DAT in 2016; 4: 60 DAT 2015 and 74 DAT in 2016; 5: 67 DAT in 2015 and 84 DAT in 2016; 6: 74 DAT in 2015 and 94 DAT in 2016 ; 7: 82 DAT in 2015 and 102 DAT in 2016; 8: 102 DAT in 2015 and 115 DAT in 2016; 9: 116 DAT in 2015 and 137 DAT in 2016.

Fig. 1. Mean cumulative fresh biomass of pruned suckers (g.plant ${ }^{-1}$ ) of 'Panzer' tomato grown with two fertilizer treatments (A, B) and four grafting treatments (C, D) in a high tunnel at Washington State University Mount Vernon Northwestern Washington Research and Extension Center at 35, 42, 53, 60, 67, 74, 82, 102 and $116 \mathrm{~d}$ after transplanting in 2015 (A, C), and 39, 52, $60,74,84,94,102,115$ and 137 DAT in 2016 (B, D) during the summer growing seasons. Data values represent non transformed means. Mean \pm standard error.

A

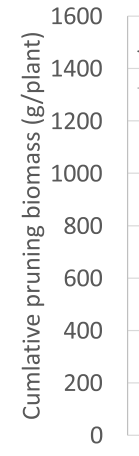

B

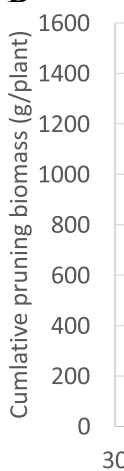
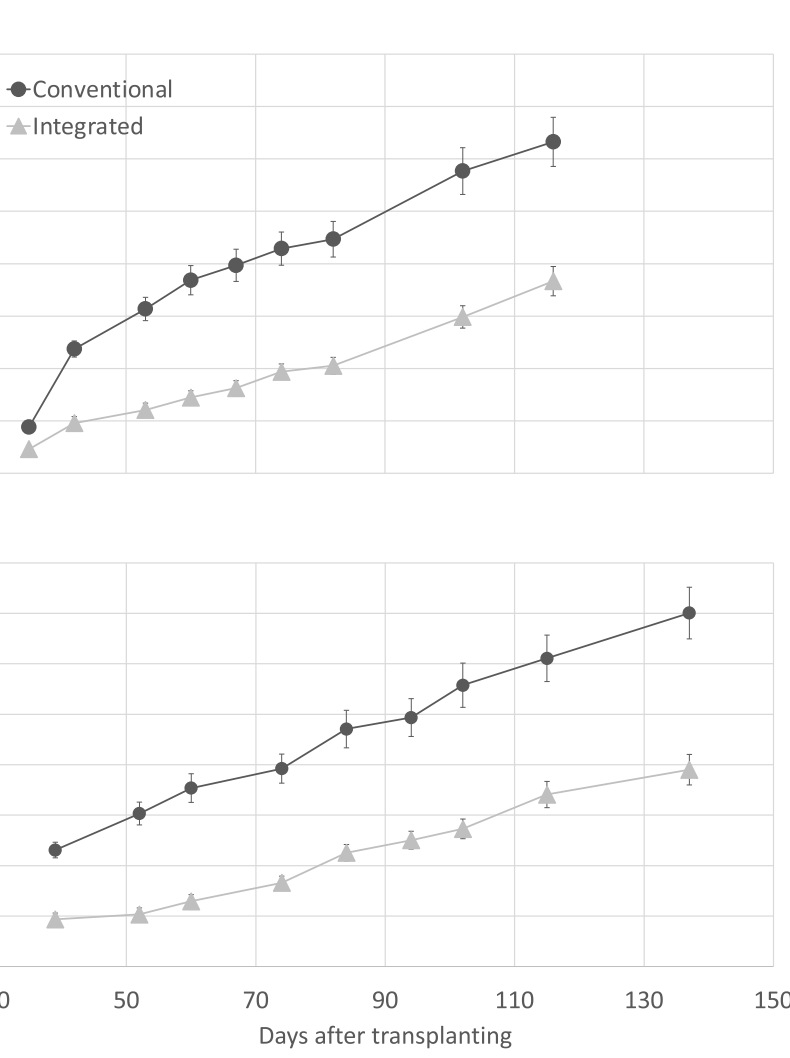

C

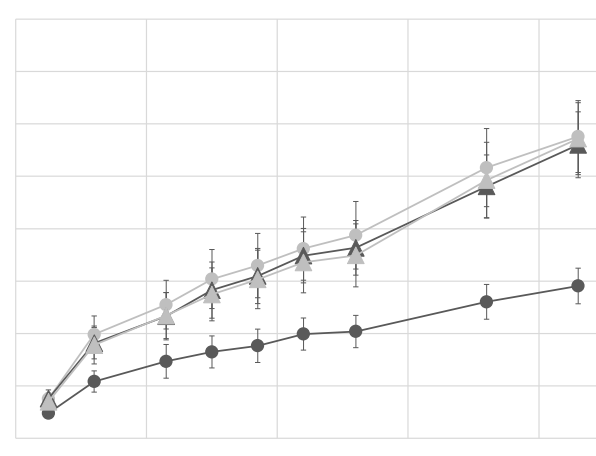

D

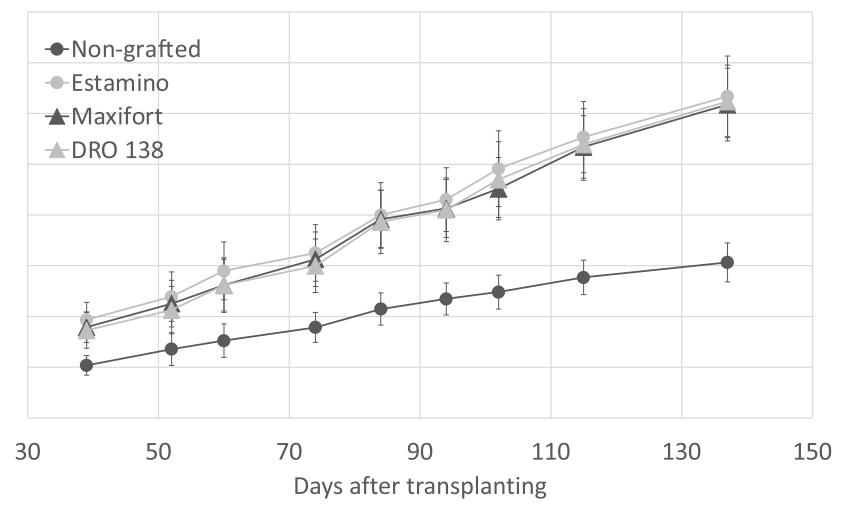


Table 5. Mean nitrate-N in plant tissue and fresh petiole sap of 'Panzer' tomato grown with two fertilizer treatments and four grafting treatments in a high tunnel at Washington State University Mount Vernon Northwestern Washington Research and Extension Center.

\begin{tabular}{|c|c|c|c|c|c|c|c|c|}
\hline & \multicolumn{8}{|c|}{ Nitrate-N in plant tissue ${ }^{a}(\mathrm{ppm})$} \\
\hline & \multicolumn{4}{|c|}{2015 (WAT) } & \multicolumn{4}{|c|}{2016 (WAT) } \\
\hline & 5 & 7 & 9 & 11 & 5 & 7 & 9 & 11 \\
\hline \multicolumn{9}{|l|}{ Fertilizer $^{b}$} \\
\hline Chemical & 378 & 350 & 389 & 129 & 480 & 1343 & 939 & 270 \\
\hline Integrated & 399 & 467 & 399 & 200 & 599 & 1528 & 1006 & 369 \\
\hline$P$ value & 0.86 & 0.14 & 0.88 & 0.45 & 0.27 & 0.17 & 0.55 & 0.16 \\
\hline \multicolumn{9}{|l|}{ Rootstock } \\
\hline DRO 138 & 365 & 482 & 274 & 118 & 577 & $1554 a$ & 929ab & 295 \\
\hline Estamino & 522 & 543 & 529 & 285 & 664 & $1687 \mathrm{a}$ & $1216 a$ & 322 \\
\hline Maxifort & 439 & 340 & 355 & 185 & 539 & $1511 a$ & 1149a & 324 \\
\hline Nongrafted & 228 & 269 & 418 & 69 & 377 & $991 b$ & $598 b$ & 338 \\
\hline \multirow[t]{4}{*}{$P$ value } & 0.36 & 0.09 & 0.12 & 0.4 & 0.31 & 0.02 & 0.01 & 0.97 \\
\hline & \multicolumn{8}{|c|}{ Nitrate-N in fresh petiole $\operatorname{sap}^{a}(\mathrm{ppm})$} \\
\hline & \multicolumn{4}{|c|}{2015 (WAT) } & \multicolumn{4}{|c|}{2016 (WAT) } \\
\hline & 5 & 7 & 9 & 11 & 5 & 7 & 9 & 11 \\
\hline \multicolumn{9}{|l|}{ Fertilizer } \\
\hline Chemical & 1168 & 982 & 442 & 283 & 1284 & 832 & 691 & 267 \\
\hline Integrated & 999 & 922 & 493 & 267 & 1434 & 1025 & 744 & 283 \\
\hline$P$ value & 0.14 & 0.57 & 0.49 & 0.47 & 0.19 & 0.09 & 0.56 & 0.54 \\
\hline \multicolumn{9}{|l|}{ Rootstock } \\
\hline DRO 138 & $1051 b$ & 1009 & 424 & 292 & 1342 & 944ab & $751 a$ & $285 a$ \\
\hline Estamino & $1452 a$ & 1158 & 523 & 280 & 1483 & $1138 \mathrm{a}$ & $848 \mathrm{a}$ & $320 a$ \\
\hline Maxifort & $1023 b$ & 873 & 429 & 290 & 1370 & $941 \mathrm{ab}$ & $794 a$ & $280 a$ \\
\hline Nongrafted & $808 b$ & 768 & 494 & 240 & 1240 & $692 b$ & $477 b$ & $214 b$ \\
\hline$P$ value & 0.004 & 0.07 & 0.72 & 0.33 & 0.27 & 0.02 & 0.04 & 0.0009 \\
\hline
\end{tabular}

Note: Data were collected at 5, 7, 9 and 11 wk after transplanting (WAT) during the summer growing seasons in 2015 and 2016. Means followed by the same letter within sampling date are not significantly different at $P<0.05$.

${ }^{a}$ All data were subjected to analysis of variance using ANOVA in JMP (version 11.0 for Windows; SAS Institute Inc., Cary, NC, USA).

${ }^{b}$ Chemical fertilizer was applied at $112 \mathrm{~N}-74 \mathrm{P}-47 \mathrm{~K}$ and $356 \mathrm{Ca} \mathrm{kg} \cdot \mathrm{ha}^{-1}$ in 2015, and $112 \mathrm{~N}-62 \mathrm{P}-43 \mathrm{~K}$ and $288 \mathrm{Ca} \mathrm{kg} \cdot \mathrm{ha}^{-1}$ in 2016 . Integrated fertilizer was composted poultry manure (nutrient application rates were $12 \mathrm{~N}-58 \mathrm{P}-26 \mathrm{~K}$ and $344 \mathrm{Ca} \mathrm{kg} \cdot \mathrm{ha}^{-1}$ in 2015, and $17 \mathrm{~N}-61 \mathrm{P}-43 \mathrm{~K}$ and $295 \mathrm{Ca} \mathrm{kg} \cdot \mathrm{ha}^{-1}$ in 2016$)$ plus nitrogen fertilizer $\left(90 \mathrm{~kg} \cdot \mathrm{ha}^{-1} \mathrm{~N}\right)$.

PM plus mineral fertilizer resulted in higher leaf $\mathrm{N}$ than PM alone, suggesting that the addition of chemical fertilizer to PM provided enhanced plant nutrition. In the current study, while there was no significant difference in nitrate- $\mathrm{N}$ between fertilizer treatments, there was a trend toward higher nitrate-N in plants grown with integrated fertilizer than those grown with chemical fertilizer. This trend may be somewhat suppressed in the present report due to the slightly lower (about 4.5\%-9\%) amount of total $\mathrm{N}$ able to be applied in the integrated treatments relative to the chemical fertilizer treatment. A lower nitrate- $\mathrm{N}$ in plant tissues may be caused by an overall greater plant growth with chemical fertilizer. As plant biomass increases, $\mathrm{N}$ concentration decreases due to an increase in the relative proportion of structural materials and storage tissues, which contain low levels 
Table 6. Mean total and marketable fruit weight $\left(\mathrm{t} \cdot \mathrm{ha}^{-1}\right)$ and number of 'Panzer' tomato grown with two fertilizer treatments in a high tunnel at Washington State University Mount Vernon Northwestern Washington Research and Extension Center during 2015 and 2016 summer growing seasons.

\begin{tabular}{|c|c|c|c|c|c|c|c|c|}
\hline & \multicolumn{4}{|l|}{$2015^{a}$} & \multicolumn{4}{|l|}{2016} \\
\hline & \multicolumn{2}{|l|}{ Total $^{b}$} & \multicolumn{2}{|c|}{ Marketable $^{c}$} & \multicolumn{2}{|l|}{ Total } & \multicolumn{2}{|c|}{ Marketable } \\
\hline & Weight & Number ${ }^{e}$ & Weight & Number & Weight & Number & Weight & Number \\
\hline \multicolumn{9}{|l|}{ Fertilizer $^{d}$} \\
\hline Chemical & 72.7 & 270 & 56.6 & 207 & 32.0 & 132 & 20.3 & 85 \\
\hline Integrated & 72.6 & 264 & 56.0 & 197 & 31.2 & 130 & 19.1 & 79 \\
\hline$P$ value & 0.96 & 0.40 & 0.81 & 0.20 & 0.58 & 0.86 & 0.37 & 0.54 \\
\hline
\end{tabular}

${ }^{a}$ All data were subjected to analysis of variance using ANOVA in JMP (version 11.0 for Windows; SAS Institute Inc., Cary, NC, USA).

${ }^{b}$ Weight (ton) and number of both marketable and unmarketable fruit per hectare.

${ }^{c}$ Marketability standard was based on USDA Grade 2, a direct market standard (USDA 1991).

${ }^{d}$ Chemical fertilizer was applied at $112 \mathrm{~N}-74 \mathrm{P}-47 \mathrm{~K}$ and $356 \mathrm{~kg} \cdot \mathrm{ha}^{-1} \mathrm{Ca}$ in 2015 , and $112 \mathrm{~N}-62 \mathrm{P}-43 \mathrm{~K}$ and $288 \mathrm{~kg} \cdot \mathrm{ha}{ }^{-1}$ $\mathrm{Ca}$ in 2016; integrated fertilizer was composted poultry manure (nutrient application rates were $12 \mathrm{~N}-58 \mathrm{P}-26 \mathrm{~K}$ and $344 \mathrm{~kg} \cdot \mathrm{ha}^{-1} \mathrm{Ca}$ in 2015, and 17N-61P-43K and $295 \mathrm{~kg} \cdot \mathrm{ha}^{-1} \mathrm{Ca}$ in 2016) plus nitrogen fertilizer $\left(90 \mathrm{~kg} \cdot \mathrm{ha}^{-1} \mathrm{~N}\right)$.

${ }^{e} 1000$ fruit per hectare.

Fig. 2. Mean total and marketable fruit number (A) and weight (B) of 'Panzer' tomato grown with four grafting treatments in a high tunnel at Washington State University Mount Vernon Northwestern Washington Research and Extension Center during 2015 and 2016 summer growing seasons.

A

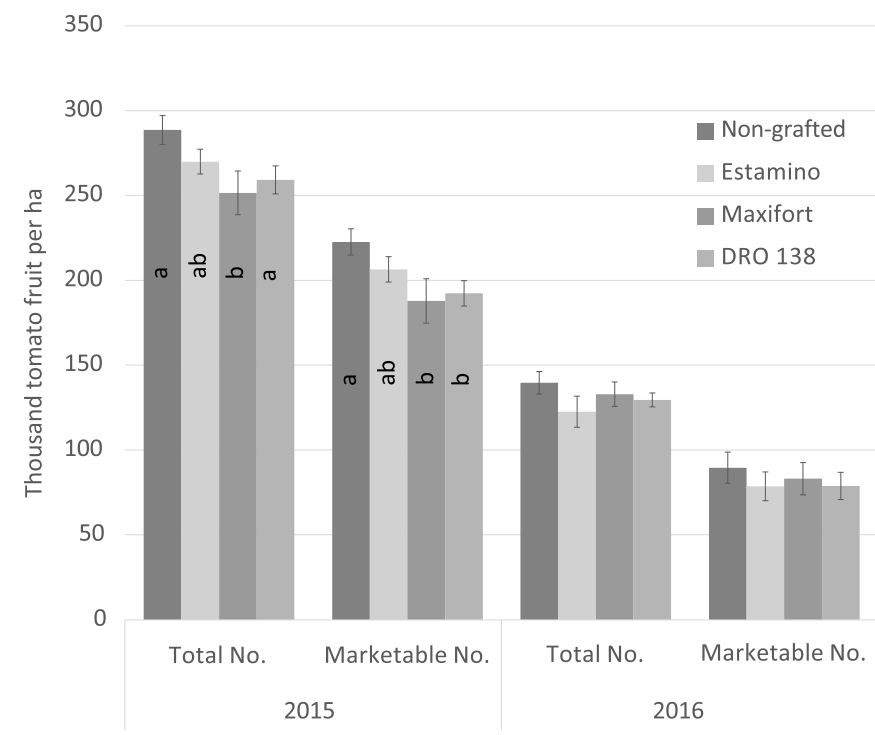

of N (Greenwood et al. 1990). Thus, integrated fertilizer may be an adequate fertilizer regime, relative to nitrate- $\mathrm{N}$ accumulation in vegetative tissues, for tomato plants in high tunnel production in northwestern Washington; and under such a regime, additional readily available nutrients early in the growing season may be necessary for crop productivity. Grafted plants had higher nitrate- $N$ concentrations than non-grafted plants, suggesting that the more vigorous root system of the rootstock may have been capable of absorbing

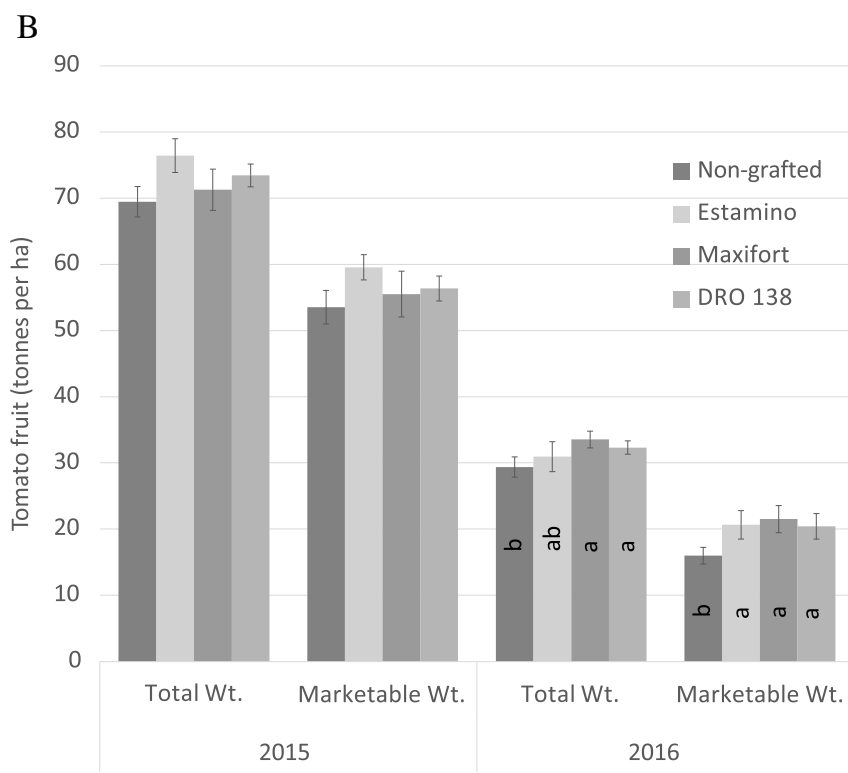

and (or) translocating plant nutrients more efficiently than the scion root system (Nawaz et al. 2016). Nitrate-N in fresh petiole sap differed slightly due to the fertilizer treatment, confirming that sap nitrate- $\mathrm{N}$ content is a sensitive indicator of plant nutrient status, and therefore a useful and efficient tool to evaluate tomato plant $\mathrm{N}$ status. Plant nutrients in chemical fertilizers are more readily available than nutrients in organic sources such as compost (Eghball et al. 2002). Rapid plant growth due to grafting may require more available nutrients early 
Table 7. Mean fruit quality parameters of 'Panzer' tomato fruit grown with two fertilizer treatments and four grafting treatments in a high tunnel at Washington State University Mount Vernon Northwestern Washington Research and Extension Center during 2015 and 2016 summer growing seasons.

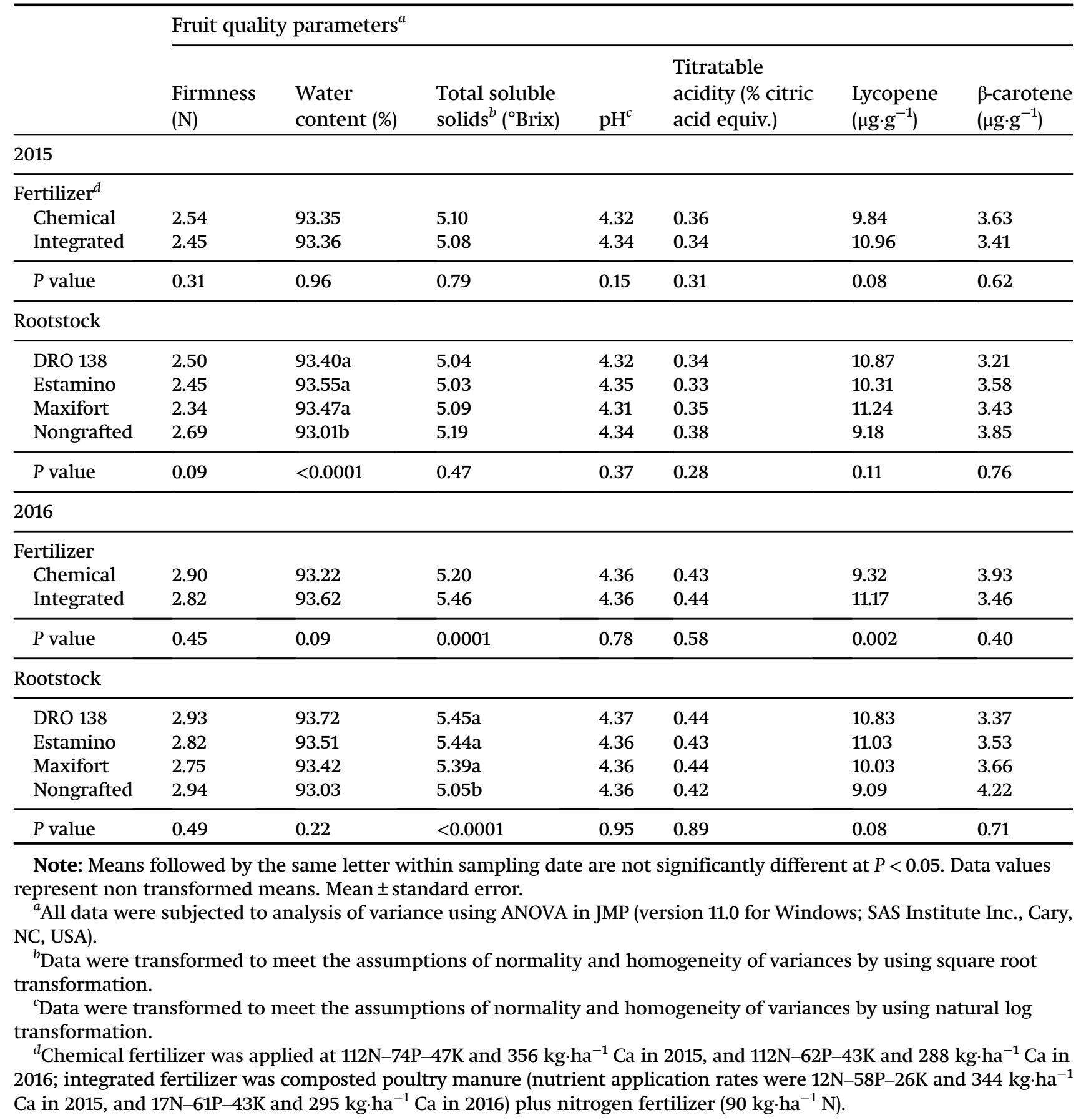

in the season, potentially increasing the compatibility of chemical fertilizers with grafted plants. Organic fertilizers could be supplemented with chemical fertilizers in an integrated approach to meet high nutrient needs early in the season. Organic fertilizers could also be applied to soil in the previous fall to allow time for organic nutrients to mineralize, becoming available to plants early in the following season (Collins et al. 2013). However, in the current study, both chemical and integrated fertilizer treatments produced similar concentrations of nitrate- $\mathrm{N}$ in plant tissue of grafted plants. More work in this area could help optimize the use of organic fertilizers with grafted tomato plants in high tunnel systems.

Number and weight of total and marketable fruit did not differ due to fertilizer source either year. These results differ from Adekiya and Agbede (2009) who found that the combination of PM plus chemical 
fertilizer resulted in higher yield of a local tomato cultivar than PM or chemical fertilizer alone. Likewise, the current results differ from Yanar et al. (2011) who reported that fruit yield of tomato 'Alida' was greater with CPM than with several organic fertilizers (Ormin, Coplex and composted cattle manure) or an inorganic fertilizer (459N-153P-498K-200S-17Ca-50 Mg kg.ha ${ }^{-1}$ ). Although high tunnels enhance environmental conditions, the relatively low temperatures in northwestern Washington provided a sub-optimal environment for tomato growth and fruit development, subsequently affecting overall $\mathrm{N}$-use efficiency from either fertilizer source, as compared with the previously mentioned studies where temperatures were likely not a limiting factor. Additionally, the lack of any significant impact of CPM in the present study could be attributed to management practices we did not evaluate, including timing and method of fertilizer application, plant architecture (i.e., pruning and trellising), and variety selection (Ilupeju et al. 2015).

Total and marketable fruit weight was greater for grafted plants than for non-grafted plants, but only in the second growing season. The average air temperature in the high tunnel in 2016 was lower than in 2015 (16.1 and $17{ }^{\circ} \mathrm{C}$, respectively), suggesting that grafting may have increased nutrient-use efficiency or other production constraints in the lower temperature conditions of the second growing season. These results seem to contrast with the findings of Buller et al. (2013) where grafting 'Cherokee Purple' onto 'Beaufort' or 'Maxifort' rootstocks did not provide any advantages for tomato yield. Likewise, Miles et al. (2015) reported that grafted heirloom tomato 'Stupice' showed no advantage over non-grafted 'Stupice'. Both of these studies were carried out in the open field in northwest Washington, where lower temperatures may have been too low for the more vigorous rootstocks to have adequately compensated. In the high tunnel environment of the current study, grafted plants tended to exhibit increased total and marketable fruit weight, though only statistically significant in the colder year. Previous studies found that rootstock genotypes present broad differences in low temperature tolerance (Kacjan-Marsic and Osvald 2004; Pogonyi et al. 2005). Given the relatively small number of rootstocks evaluated in this study and the prior open field studies in Washington, it is reasonable to expect differences between performance of grafted tomato in high tunnels compared with open field production, especially in a region where summer temperatures do not reach the optimal range for tomato growth and development.

There was no significant effect due to fertilizer source on fruit quality parameters measured in this study, except TSS and lycopene content were higher for fruit grown with integrated fertilizer than with chemical fertilizer in 2016. Application of CPM could enhance soil physical properties (Van Noordwijk et al.1993; Celik et al. 2004), as well as improve root extension, which can promote higher water and nutrient uptake by plants and subsequently enhance starch production via photosynthesis (Chen and Avnimelech 1986). Starch is accumulated in green tomato, and levels decline with the onset of fruit ripening with an accompanying rise in soluble solids (Davies and Cocking 1965; Eskin 2000). The positive effect of applying PM is reflected in the increased levels of TSS and lycopene. Likewise, increased TSS in fruit from grafted plants in 2016 relative to non-grafted plants may have been due to improved nutrient absorption in the rootstocks. Fruit from grafted tomato plants had higher water content than fruit from non-grafted plants, though only statistically significant in 2015 despite a greater relative difference in 2016. An inverse relationship exists between water content and TSS in tomato fruit (Mitchell et al. 1991). It is likely that the relationship between fruit water content and TSS could be affected by grafting especially where temperatures might impact transpiration and translocation of photosynthates to the fruit; and, we recommend further inquiry into this relationship.

\section{Conclusion}

While the integrated fertilizer treatment produced less growth than chemical fertilizer, especially early in the growing season, both treatments produced comparable nitrate- $\mathrm{N}$ concentrations in tomato plant tissues, comparable total and marketable yields; and, the integrated fertilizer improved TSS and lycopene content of tomato fruit. Given that organic fertilizers can often take more time for nutrients to become available, an integrated fertility regimen, incorporating both chemical and organic fertilizer sources, early in the season may provide adequate plant nutrition, increasing soil organic matter without negatively impacting yield or fruit quality. Grafting enhanced plant growth, nitrate-N concentrations, and tomato fruit yield in high tunnel production in northwestern Washington.

\section{Acknowledgements}

Technical assistance provided by Patricia Kreider and Edward Scheenstra, and funding support provided by the Libyan Ministry of Higher Education \& Scientific Research, USDA-NIFA SCRI Grant No. 2011-51181-30963, and NIFA Hatch project 1017286, are gratefully acknowledged.

\section{References}

Adekiya, A.O., and Agbede, T.M. 2009. Growth and yield of tomato (Lycopersicon esculentum Mill) as influenced by poultry manure and NPK fertilizer. Emir. J. Food Agric. 21(1): 10-20. doi:10.9755/ejfa.v21i1.5154.

AgWeatherNet. 2016. The average 20 years air temperature of Western Washington. Washington State University Mount Vernon Station. [Online]. Available from http://weather. wsu.edu/ [6 Dec. 2016].

Alizadeh, P., Fallah, S., and Raiesi, F. 2012. Potential N mineralization and availability to irrigated maize in a calcareous soil 
amended with organic manures and urea under field conditions. Int. J. Plant Prod. 6(4): 493-512. doi:10.22069/ ijpp.2012.762.

Andersen, P.C., Rhoads, F.M., Olson, S.M., and Brodbeck, B.V. 1999. Relationships of nitrogenous compounds in petiole sap of tomato to nitrogen fertilization and value of these compounds as a predictor of yield. HortScience, 34(2): 254-258. doi:10.21273/HORTSCI.34.2.254.

Blomgren, T., and Frisch, T. 2007. High tunnels: using low-cost technology to increase yields, improve quality, and extend the season. University of Vermont Center for Sustainable Agriculture. [Online]. Available from https://www.sare.org/ resources/high-tunnels [26 Aug. 2015].

Buller, S., Inglis, D., and Miles, C. 2013. Plant growth, fruit yield and quality, and tolerance to verticillium wilt of grafted watermelon and tomato in field production in the Pacific Northwest. HortScience, 48(8): 1003-1009. doi:10.21273/ HORTSCI.48.8.1003.

Carey, E.E., Jett, L., Lamont, W.J., Jr, Nennici, T.T., Orzolek, M.D., and Williams, K.A. 2009. Horticulturral crop production in high tunnel in the United States: a snapshot. HortTechnology, 19(1): 37-43. doi:10.21273/HORTSCI.19.1.37.

Celik, I., Ortas, I., and Kilic, S. 2004. Effects of compost, mycorrhiza, manure and fertilizer on some physical properties of a Chromoxerert soil. Soil Tillage Res. 78: 59-67. doi:10.1016/ j.still.2004.02.012.

Ceylan, S., Alan, Ö., and Elmaci, Ö.L. 2018. Effects of grafting on nutrient element content and yield in watermelon. Ege Üniv. Ziraat Fak. Derg. 55(1): 67-74. doi:10.20289/zfdergi.390891.

Chen, Y., and Avnimelech, Y.1986. The role of organic matter in modern agriculture. Nijhoff, Dordrecht, Holland, the Netherlands.

Collins, D., Miles, C., Cogger, C., and Koenig, R. 2013. Soil fertility in organic systems: a guide for gardeners and small acreage farmers. A Pacific Northwest Extension Publication. PNW646.

Cowan, J.S., Miles, C.A., Andrews, P.K., and Inglis, D.A. 2014. Biodegradable mulch performed comparably to polyethylene in high tunnel tomato (Solanum lycopersicum L.) production. J. Sci. Food Agric. 94(9): 1854-1864. doi:10.1002/jsfa. 6504. PMID:24288255.

Davies, J.N., and Cocking, E.C. 1965. Changes in carbohydrates, proteins and nucleic acids during cellular development in tomato fruit locule tissue. Planta, 67: 242-253. doi:10.1007| BF00385654.

Demir, K., Sahin, O., Kadioglu, Y.K., Pilbeam, D.J., and Gunes, A. 2010. Essential and non-essential element composition of tomato plants fertilized with poultry manure. Sci. Hortic. 127: 16-22. doi:10.1016/j.scienta.2010.08.009.

Eghball, B., Wienhold, B.J., Gilley, J.E., and Eigenberg, R.A. 2002. Mineralization of manure nutrients. Biological Systems Engineering: Papers and Publications. Paper 139. [Online]. Available from http://digitalcommons.unl.edu/ biosysengfacpub/139 [6 Dec. 2016].

Eskin, N.A.M. 2000. Quality and preservation of vegetables. CRC Press, Inc., Boca Raton, FL, USA.

Francis, P.B., and Stark, C.R. 2012. Heirloom tomato production in conventional and transitional-organic managed systems. HortScience, 47(8): 1034-1037. doi:10.21273/HORTSCI. 47.8.1034.

Ghimire, S., Wszelaki, A.L., Moore, J.C., Inglis, D.A., and Miles, C.A. 2018. The use of biodegradable mulches in pie pumpkin production in two diverse climates. HortScience, 53(3): 288-294. doi:10.21273/HORTSCI12630-17.

Greenwood, D.J., Lemaire, G., Gosse, G., Cruz, P., Draycott, A., and Neeteson, J.J. 1990. Decline in percentage $\mathrm{N}$ of $\mathrm{C}_{3}$ and $\mathrm{C}_{4}$ crops with increasing plant mass. Ann. Bot. 66(4): 425-436. doi:10.1093/oxfordjournals.aob.a088044.
Han, J.S., Park, S., Shigaki, T., Hirschi, K.D., and Kim, C.K. 2009. Improved watermelon quality using bottle gourd rootstock expressing a $\mathrm{Ca}^{2+} / \mathrm{H}^{+}$antiporter. Mol. Breed. 24: 201-211. doi:10.1007/s11032-009-9284-9.

Hochmuth, G.J. 1994. Efficiency ranges for nitrate-nitrogen and potassium for vegetable petiole sap quick tests. HortTechnology, 4(3): 218-222. doi:10.21273/HORTTECH. 4.3.218.

Hochmuth, G.J., Maynard, D., Vavrina, C., and Hanlon, E. 1991. Plant tissue analysis and interpretation for vegetable crops in Florida. University of Florida Cooperative Extension Service Publication SS-VEC-42, Gainesville, FL, USA.

Ilupeju, E.A.O., Akanbi, W.B., Olaniyi, J.O., Lawal, B.A., Ojo, M.A., and Akintokun, P.O. 2015. Impact of organic and inorganic fertilizers on growth, fruit yield, nutritional and lycopene contents of three varieties of tomato (Lycopersicon esculentum (L.) Mill) in Ogbomoso, Nigeria. Afr. J. Biotechnol. 14(31): 2424-2433. doi:10.5897/AJB10.1902.

Isah, A.S., Amans, E.B., Odion, E.C., and Yusuf, A.A. 2014. Growth rate and yield of two tomato varieties (Lycopersicon esculentum Mill) under green manure and NPK fertilizer rate Samaru Northern Guinea Savanna. Int. J. Agron. 2014: 932759. doi:10.1155/2014/932759.

Johnson, S., Kreider, P., and Miles, C. 2011. Vegetable grafting: eggplants and tomatoes. Washington State University Extension Fact Sheet. FS052E.

Kacjan-Marsic, N., and Osvald, J. 2004. The influence of grafting on yield of two tomato cultivars (Lycopersicon esculentum Mill.) grown in a plastic house. Acta Agric. Slov. 83: 243-249.

Kelbert, D.G.A., Everett, P.H., Overman, A.J., Geraldson, C.M., Kelsheimer, E.G., Jones, J.P., et al. 1966. Tomato production on the sandy soils of south Florida. Bulletin 710. University of Florida, Gainesville, FL, USA. [Online]. Available from http://ufdc.ufl.edu/UF00027583/00001 [23 Mar. 2021].

Khah, E.M., Kakava, E., Mavromatis, A., Chachalis, D., and Goulas, C. 2006. Effect of grafting on growth and yield of tomato (Lycopersicon esculentum Mill.) in greenhouse and open-field. J. Appl. Hortic. 8(1): 3-7. doi:10.37855/jah.2006. v08i01.01.

Kirda, C., Cetin, M., Dasgan, Y., Topcu, S., Kaman, H., Ekici, B., et al. 2004. Yield response of greenhouse grown tomato to partial root drying and conventional deficit irrigation. Agric. Water Manage. 69: 191-201. doi:10.1016/j.agwat.2004.04.008.

Kjeldahl, J. 1883. Neue methode zur bestimmung des stickstoffs in organischen körpern [New method for the determination of nitrogen in organic substances]. Z. Anal. Chem. 22: 366-382. doi:10.1007/BF01338151.

Kubota, C., McClure, M.A., Kokalis-Burelle, N., Bausher, M.G., and Rosskopf, E.N. 2008. Vegetable grafting: history, use, and current technology status in North America. HortScience, 43(6): 1664-1669. doi:10.21273/HORTSCI.43. 6.1664.

Lamont, W. 2009. Overview of the use of high tunnels worldwide. HortTechnology, 19(1): 25-29. doi:10.21273/ HORTSCI.19.1.25.

Lee, J.-M. 1994. Cultivation of grafted vegetables. I. Current status, grafting methods, and benefits. HortScience, 29(4): 235-239. doi:10.21273/HORTSCI.29.4.235.

Lee, J.-M. 2003. Advances in vegetable grafting. Chron. Hortic. 43: 13-19.

Lee, J.-M., Kubota, C., Tsao, S.J., Bie, Z., Hoyos Echevarria, P., Morra, L., and Oda, M. 2010. Current status of vegetable grafting: diffusion, grafting techniques, automation. Sci. Hortic. 127(2): 93-105. doi:10.1016/j.scienta.2010.08.003.

Lee, S.G. 2007. Production of high quality vegetable seedling grafts. Acta Hortic. 729: 169-174. doi:10.17660/ActaHortic. 2007.759.12 
Locascio, S.J., Hochmuth, G.J., Rhoads, F.M., Olson, S.M., Smajstrla, A.G., and Hanlon, E.A. 1997. Nitrogen and potassium application scheduling effect on drip-irrigated tomato yield and leaf tissue analysis. HortScience, 32(2): 230-235. doi:10.21273/HORTSCI.32.2.230.

Louws, F.J., Rivard, C.L., and Kubota, C. 2010. Grafting fruiting vegetables to manage soilborne pathogens, foliar pathogens, arthropods and weeds. Sci. Hortic. 127(2): 127-146. doi:10.1016/j.scienta.2010.09.023.

Lovatt, J., Fullelove, G., Wright, R., Meurant, N., Barnes, J., and O'Brien, R. 1998. Tomato information kit. Department of Primary Industries Queensland, Brisbane, Australia.

Martinez-Ballesta, M.C., Alcaraz-Lopez, C., Muries, B., MotaCadenas, C., and Carvajal, M. 2010. Physiological aspects of rootstock-scion interactions. Sci. Hortic. 127: 112-118. doi:10.1016/j.scienta.2010.08.002.

McMaster, G.S., and Wilhelm, W.W. 1997. Growing degree-days: one equation, two interpretations. Agric. For. Meteorol. 87: 291-300. doi:10.1016/S0168-1923(97)00027-0.

Miles, C., Wallace, R., Wszelaki, A., Martin, J., Cowan, J., Walters, T., and Inglis, D. 2012. Deterioration of potentially biodegradable alternatives to black plastic mulch in three tomato production regions. HortScience, 47(9): 1270-1277. doi:10.21273/HORTSCI.47.9.1270.

Miles, C., Wimer, J., and Inglis, D. 2015. Grafting eggplant and tomato for verticillium wilt resistance. Acta Hortic. 1086: 113-118. doi:10.17660/ActaHortic.2015.1086.13.

Mitchell, J.P., Shennan, C., Grattan, S.R., and May, D.M. 1991. Tomato fruit yield and quality under water deficit and salinity. J. Am. Soc. Hortic. Sci. 116(2): 215-221. doi:10.21273/ JASHS.116.2.215.

Montri, A., and Biernbaum, J.A. 2009. Management of the soil environment in high tunnels. HortTechnology, 19(1): 34-36. doi:10.21273/HORTSCI.19.1.34.

National Resource Conservation Service. 2010. Web soil survey. Soil Survey Staff, Natural Resources Conservation Service, United States Department of Agriculture. [Online]. Available from http://websoilsurvey.nrcs.usda.gov/ [10 May 2015].

Navarro, J.M., Flores, P., Garrido, C., and Martinez, V. 2006. Changes in the contents of antioxidant compounds in pepper fruits ripening stages, as affected by salinity. Food Chem. 96: 66-73. doi:10.1016/j.foodchem.2005.01.057.

Nawaz, M.A., Imtiaz, M., Kong, Q., Cheng, F., Ahmed, W., Huang, Y., and Bie, Z. 2016. Grafting: a technique to modify ion accumulation in horticultural crops. Front. Plant Sci. 7: 1457. doi:10.3389/fpls.2016.01457. PMID:27818663.

Paroussi, G., Bletsos, F., Bardas, G.A., Kouvelos, J.A., and Klonari, A. 2007. Control of fusarium and verticillium wilt of watermelon by grafting and its effect on fruit yield and quality. Acta Hortic. 729: 281-285. doi:10.17660/ActaHortic.2007. 729.46.

Peregrine, W.T.H., and Bin Ahmad, K. 1982. Grafting - a simple technique for overcoming bacterial wilt in tomato. Trop. Pest Manage. 28: 71-76. doi:10.1080/09670878209370676.

Pogonyi, A., Pek, Z., Helyes, L., and Lugasi, A. 2005. Effect of grafting on the tomato's yield, quality and main fruit components in spring forcing. Acta Aliment. 34: 453-462. doi:10.1556/AAlim.34.2005.4.12.

Powell, M., Gunderson, B., Cowan, J., Miles, C.A., and Inglis, D.A. 2014. The effect of open-ended high tunnels in western Washington on late blight and physiological leaf roll among five tomato cultivars. Plant Dis. 98(12): 1639-1647. doi:10.1094/PDIS-12-13-1261-RE. PMID:30703891.

Reeve, J., and Drost, D. 2012. Yield and soil quality under transitional organic high tunnel tomatoes. HortScience, 47(1): 38-44. doi:10.21273/HORTSCI.47.1.38.

Reid, J., Klotzbach, K., and Hoover, N. 2012. 2011 High tunnel tomato variety trial. Cornell Univ. Coop. Ext. Publ. 8(2): 3-20.

Rivard, C.L., and Louws, F.J. 2008. Grafting to manage soilborn diseases in heirloom tomato production. HortScience, 43(7): 2104-2111. doi:10.21273/HORTSCI.43.7.2104.

Ruiz, J.M., Belakbir, L., Ragala, J.M., and Romero, L. 1997. Response of plant yield and leaf pigments to saline conditions: effectiveness of different rootstocks in melon plants (Cucumis melo L.). Soil Sci. Plant Nutr. 43: 855-862. doi:10.1080/00380768.1997.10414652.

Sadler, G.D., and Murphy, P.A. 2003. pH and titratable acidity. Pages 207-222 in Food analysis. 3rd ed. Kluwer Academic/ Plenum Publishers.

Sakata, Y., Ohara, T., and Sugiyama, M. 2007. The history and present state of the grafting of cucurbitaceous vegetables in Japan. Acta Hortic. 731: 159-170. doi:10.17660/ActaHortic. 2007.731.22.

Santa-Cruz, A., Martinez-Rodriguez, M.M., Perez-Alfocea, F., Romero-Aranda, R., and Bolarin, M.C. 2002. The rootstock effect on the tomato salinity response depends on the shoot genotype. Plant Sci. 162: 825-831. doi:10.1016/S0168-9452(02) 00030-4.

Stone, D.M., and Elioff, J.D. 1998. Soil properties and Aspen development five years after compaction and forest floor removal. Can. J. Soil Sci. 78(1): 51-58. doi:10.4141/S97-026.

United States Department of Agriculture (USDA). 1975. United States standards for grades of fresh: color classification requirements in tomatoes. Visual aid TM-L-1. The John Henry Company, Lansing, MI, USA.

United States Department of Agriculture (USDA). 1991. United States standards for grades of fresh tomatoes. [Online]. Available from https://www.ams.usda.gov/sites/ default/files/media/Tomato_Standard\%5B1\%5D.pdf

United States Department of Agriculture (USDA). 2016. Vegetables 2015 summary. [Online]. Available from http://usda.mannlib.cornell.edu/usda/current/VegeSumm/ VegeSumm-02-04-2016.pdf.

Van Noordwijk, M., Schhonderbeek, D., and Kooistra, M.J. 1993. Root-soil contact of grown winter wheat. Geoderma, 56: 277-286. doi:10.1016/0016-7061(93)90117-4.

Yanar, D., Gebologlu, N., Yanar, Y., Aydin, M., and Cakmak, P. 2011. Effect of different organic fertilizers on yield and fruit quality of indeterminate tomato (Lycopersicon esculentum). Sci. Res. Essays, 6(17): 3623-3628. doi:10.5897/SRE10. 1083. 